\title{
MANAGING INFORMATION FLOW IN SELF- ORGANISING NETWORKS OF COMMUNICATION BETWEEN CONSTRUCTION PROJECT PARTICIPANTS
}

\author{
E. RADZISZEWSKA-ZIELINA ${ }^{1}$, G. ŚLADOWSKI , E. KANIA, \\ B. SROKA, B. SZEWCZYK
}

\begin{abstract}
Construction projects are characterised by complexity in the technical, organisational and environmental sphere. The organisational complexity of such projects makes it necessary to manage relationships between actors who fulfil various functions. Formal organisational structures that have been developed for this purpose do not always reflect the actual relationships between construction project participants. In literature, scholars more and more often point to the need to identify and monitor such informal relationships and attempt to manage them in order to effectively carry out projects. Structural analysis of so-called self-organising networks of relationships between project participants is carried out on the basis of established structural measures by performing Social Network Analysis (SNA). In a situation when inappropriate communication between project participants relative to management staff expectations is detected, interventions meant to improve communication in such networks are possible. The goal of the article is proposing an optimisation-oriented approach to planning such interventions while taking various constraints, such as communication costs, into consideration. As a part of this optimisation, the authors proposed a method from the heuristic methods group. This solution will support decision-making in terms of intervening within an informal relationship structure. The method was presented on the example of an actual construction project involving the construction of a complex of housing buildings. the self-organising network structure was defined on the basis of a survey carried out among the project's participants and concerned communication between them over a four-week period. As a result of the structural network analysis, abnormalities in communication between project participants were detected. The optimisation method developed by the authors pointed to possibilities of improving communication effectiveness within this network. The effects of the analysis confirmed the application potential of the method that was presented.
\end{abstract}

Keywords: Social-network analysis (SNA), construction management, optimisation, information flow,

\section{INTRODUCTION}

Contractual formal organisational structures of construction projects regulate the expected information flow between participants involved in carrying out said projects. However, in reality, many relationships between the aforementioned participants have an informal character during

\footnotetext{
1 Assoc. Prof. PhD. Eng., Cracow University of Technology, Faculty of Civil Engineering, ul. Warszawska 24, 31-155 Cracow, Poland, e-mail: eradzisz@L3.pk.edu.pl
} 
the carrying out of said projects, while information flow paths between them are invisible from the perspective of a formal organisational structure [1]. In addition, as it turns out, many essential decisions are not made at the level of formal organisational structures (which are not always being prepared for every project), but are a result of the aforementioned informal relationships between construction project participants. The topography of self-organising information exchange networks is evolutionary and complex, as the actors in question seek links that make it easier to perform their project roles (so that they can do so quickly, efficiently and in order to maximise profits under conditions of uncertainty) [2]. Identifying and understanding these informal relationships and any undesirable dysfunctions concerning construction project participants requires that these relations be mapped in the form $\backslash$ of social networks [3,4]. The concept of social network analysis and terms like centrality and social isolation are derived from sociometry, which was established in the previous century by J.L. Moreno [5]. Since the 1970's a significant development in research on social networks using graph theory has taken place. Studies of social interactions using SNA (Social network analysis) have found application in many fields, such as sociology, anthropology, epidemiology, economics, management or information science. The first applications of SNA in construction were associated with analysing problems in communication between construction project participants [6,7]. Other research fields associated with construction that utilise social network analysis include knowledge management [8], information processing and dissemination [9], comparing commission types [10], exchanging information in the context of construction site health and safety [11], identifying gaps in organisational structures [12], investigating relationships in Public-Private Partnerships (PPP) [13] or the problem of globalisation in organisational structures [14]. The examples of using network-based approaches in management in construction mentioned above are still a rarity [15,16] when compared to other management disciplines [17]. There is thus still a need to develop this concept. The workings of the method developed by the authors has been demonstrated on a practical example of a construction project involving the construction of a complex of housing building in Katowice.

\section{RESEARCH GOAL}

Some of the latest studies focusing on analysing formal and informal relationships between project participants concern detecting (in the early stage of a project) structural problems in information exchange between project participants [18] both during the design phase [2] and the construction phase [19] of development projects. Literature on the subject features proof of the relationship between the structural position of participants in the communication network and their coordination activity, understood as an organised process of resource management in construction projects. The more central the position of a given participant in the context of information flow within the communication network, the greater that participant's coordination activity [15]. Monitoring the dynamic evolution of such self-organising networks of participants, understanding the various informal network roles that participants take on depending on their position within the relationship structure and detecting any dysfunctions in the structure of relationships between these participants can require intervention to be performed by management staff in order to improve information flow within the network. Management staff intervention into the structure of such 
relationships should be optimal in the context of set project goals [20,2]. In literature there is a lack of methods that support making such decisions. The goal of this article is to develop a method that can aid management staff in controlling information flow within self-organising networks within construction projects.

\section{THE METHOD}

\subsection{NETWORK MODEL STRUCTURE AND STRUCTURAL ANALYSIS}

The verbal description of informal relationships in the context of information flow between the participants of the analysed construction project is represented by a network based on a directed graph, defined below. The directed graph (digraph) $\mathrm{S}$ will be a graph composed of a set of nodes (which symbolise actors or organisations) $\mathrm{V}(\mathrm{S})$ and a set of links (symbolising relationships in the context of information sharing) $\mathrm{A}(\mathrm{S})$ which are ordered pairs of such nodes. If $\mathrm{S}$ is a directed graph and $s, t \in V(S)$, then we can draw a directed link from vertex $s$ to $t$, as a pair $(s, t)$. The direction of the link is shown on drawings in the form of an arrowhead.

The structural analysis of such a network based on various structural measures (Wasserman and Faust 1994) will make it possible to determine the position of participants in the context of information flow within this self-organising communication network. We know from graph theory that the position (either central or isolated) that an actor occupies within the network can either increase or decrease their access to valuable network resources (Pryke 2018). Therefore there is a dependency between the structural position of an actor within the communication network and their capacity to control information flow (Hossain 2009).

Literature on the subject points to three basic measures of centrality featured in social network analysis (Freeman, 1979)

Degree centrality - the amount of direct links between a given node and other nodes. It is the simplest measure of a node's significance within the network. The higher the degree centrality, the more a given node is significant within the network. As a part of degree centrality we can distinguish the in-degree and out-degree centrality of a node. Degree centrality can be determined using the following formula [21]:

$$
C_{D}(e)=\frac{\text { in_degree }(e)+\text { out_degree }(e)}{2(n-1)}
$$

Where:

$e$ - given node,

$n-$ total number of links, 
in_degree (e) - in-degree centrality of node e - the number of ties inbound for node e, out_degree (e) - out-degree centrality of node $\mathrm{e}$ - the number of direct outbound ties from node e.

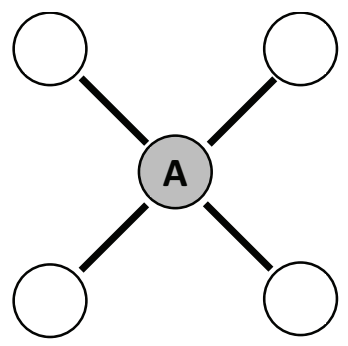

Fig 1 Interpretation of degree centrality within a network of information flow [1]

The drawing above presents a simple example of an undirected communication network. The node located at the end of each path has the lowest degree centrality within the network. The central node A has the greatest degree centrality in this network. It is connected with all the remaining nodes.

Eigenvector centrality - is a measure of centrality that takes into consideration the links of neighbouring nodes. This measure defines the relative importance of a node within the network, indicating which nodes connect with the most well-connected of the network's nodes. It is an essential measure in the case of complex communication networks and is expressed through the following formula [22]:

$$
A x=\lambda x
$$

Where:

$A$ - neighbourhood matrix,

$\lambda$ - the highest eigenvalue of the neighbourhood matrix,

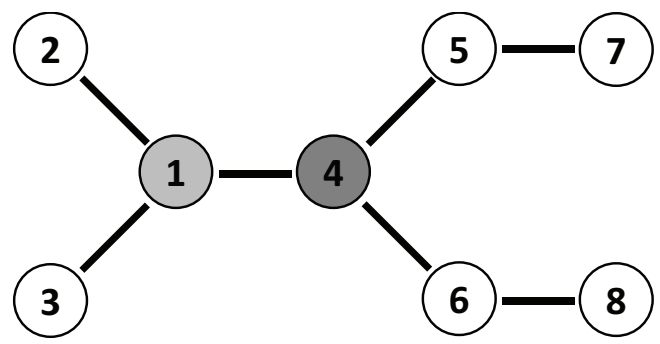

Fig 2 Interpretation of eigenvector centrality within a network of information flow [1] 
The drawing above depicts two nodes with the same degree centrality (1 and 4). Each of these nodes is directly connected with two other nodes. If we take secondary connections into consideration, then the significance of node 4 will be greater, as nodes 5 and 6 are connected to additional nodes.

Betweenness centrality - is the ratio between the shortest paths between two nodes that cross through a given node and the total amount of all shortest paths. This measure expresses the significance of a position in transferring information across the network. Betweenness centrality is expressed using the following formula [23]:

$$
C_{B}(e)=\sum_{s, t \in V} \frac{\sigma(s, t \mid e)}{\sigma(s, t)}
$$

Where:

$\sigma(s, t)$ - the number of the shortest paths between nodes s and $\mathrm{t}$,

$\sigma(s, t \mid e)$ - the number of the shortest paths between nodes s and $\mathrm{t}$, crossing through node e, which is a different node than $\mathrm{s}$ and $\mathrm{t}$.

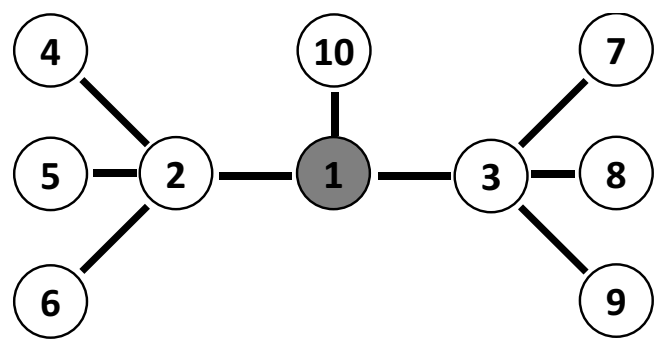

Fig 3 Interpretation of betweenness centrality in a network of information flow [1]

When looking at the drawing, we can observe that nodes 1, 2 and 3 have similar degree centrality values (nodes 2 and 3 each have four links, while node 1 has three links). If we look at the capacity of each node to control other nodes, then node 1 is in the most significant position within the network. In communication networks, node 1 is capable of controlling and steering the flow of information within the network. Whether it becomes an intermediary in spreading information or an undesired node blocking its flow within the network depends on the orientation of its links. In extreme situations, this node defines network cohesion.

\subsection{OPTIMISATION TASK FORMULATION}

Identifying and understanding the informal roles of project participants that are dependent on their position within the network is the starting point for managing such an organisation while carrying out a construction project. Identifying participant dysfunction within a self-organising communication network as a part of carrying out a project requires the manager (decision-maker) to 
appropriately intervene in order to improve information flow within the network. It is expected that the intervention is to be at least suboptimal. To this end, the authors of the article proposed the following general optimisation model.

Parameters: S - directed graph defining communication within the social network

$w_{i, j}$ - weight set for measure i of actor $\mathrm{j}$

$c_{e}$ - amount of links set for introduction to the network

$P=\left\{e_{1}, e_{2}, \ldots, e_{k}\right\}-$ prohibitions set

Goal function:

$$
F(S+E)=\frac{\sum_{j=1}^{m} \sum_{i=1}^{n} w_{i, j}\left(1-x_{j}^{i}(\mathrm{~S}+\mathrm{E})\right)^{2}}{\sum_{j=1}^{m} \sum_{i=1}^{n} w_{i, j}},
$$

where:

$x_{j}^{i}(S+E)-$ value of measure $x^{i}$ for participant $\mathrm{j}$ in graph $\mathrm{S}+\mathrm{E}$

$n$ - number of analysed measures

$m$ - number of actors within the network

Decision variables:

$E=\left\{e_{1}, e_{2}, \ldots, e_{c}\right\}$, where $e_{i}=(s, t), \mathrm{e}_{i} \notin S$ is the link connecting $s$ with node $t$ while $c$ is the number of introduced links.

Constraints:

$\bigwedge_{e \in E} e \notin P$

Prohibition set $P=\left\{e_{1}, e_{2}, \ldots, e_{k}\right\}$ defines which nodes are prohibited from forming a link between each other.

$$
c=c_{e}
$$

The number of introduced links $c$ must be equal to the number of set links that are to be introduced $c_{e}$.

In practice, during an optimal intervention within a communication network, the decision-maker should limit the maximum amount of new links introduced between project actors due to the costs of building a new link and the operational costs associated with maintaining it, which should be minimised as a matter of principle. More on the subject of communication can be found in [1]. 


\subsection{PROPOSED OPTIMISATION TASK SOLVING METHOD}

The above problem is a discrete optimisation problem. In order to solve it, the authors proposed an approximate metaheuristic simulated annealing algorithm (SA). This algorithm uses an analogy to the thermodynamic process of cooling a solid body in order to plot a search trajectory from a local extreme [24].

When using the algorithm, set values of the following parameters are defined first: $T_{0}$ - initial temperature, $T_{N}$ - minimum temperature, $\lambda$ - temperature decrease parameter. The following dependency should be in effect: $T_{0}>T_{N}$. $T_{N}$ should be set at an appropriately low value, close to zero.

By $N\left(E_{i-1}\right)$ we should understand the environment for task $E_{i-1}$. The environment was set so that $N\left(E_{i-1}\right)=E_{i-1}-e_{\text {remove }}+e_{\text {add }}$, where $e_{\text {remove }} \in E_{i-1}$ and $e_{\text {add }} \in \bar{S} \wedge e_{l} \notin P \wedge e_{l} \notin E_{i-1}(\bar{S}$ means a supplementation of graph $S$ ). The method of generating a new solution $E \in N\left(E_{i-1}\right)$ has been shown on figure 4 . Links coloured in black are links that exist in graph $S$. The colour red signifies links that belong to solutions $E_{i-1}$ and $E$, respectively. In solution $E$ link $(5,2)$ was replaced with link $(4,5)$.
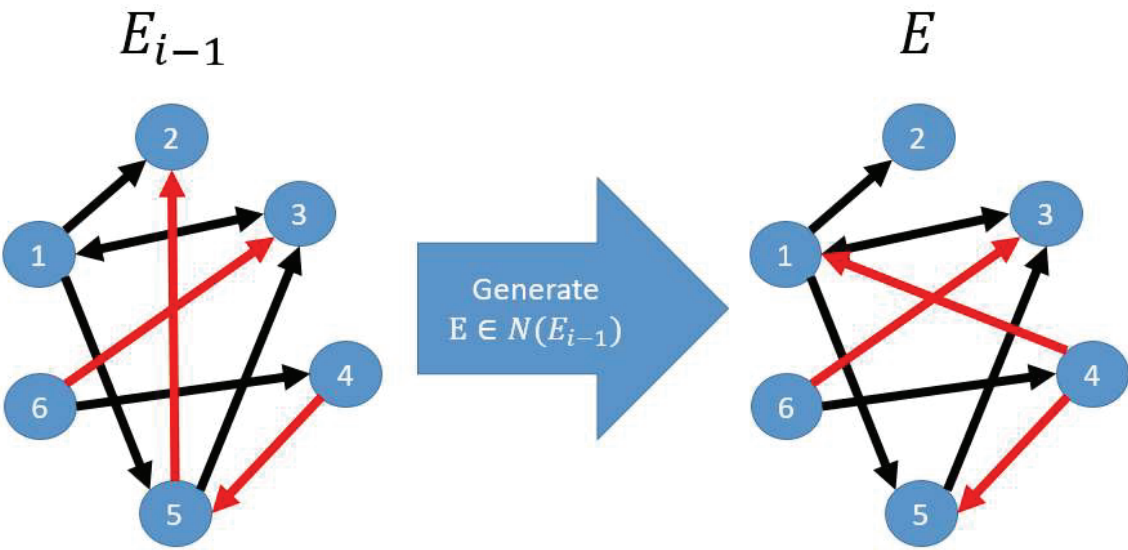

Fig 4. Conceptual scheme of plotting a new solution in environment $N\left(E_{i-1}\right)$

Below is a presentation of the stages of the SA-based algorithm, for the purposes of the information flow network optimisation task.

Stage 0. Identify links within the social network described using directed graph $S$. The number of new links introduced into the graph $c=c_{e}$. Matrix $w_{i, j}$.

Stage 1. Determine initial solution $E_{0}=\left\{e_{1}, e_{2}, \ldots, e_{c}\right\}$ so that $\Lambda_{e \in E_{0}}$ e $\notin S \wedge$ e $\notin P$. Substitute $E_{\text {best }}=E_{0}, F_{0}=F\left(S+E_{0}\right), F_{\text {best }}=F_{0}, i=0$. 
Stage 2.Perform stages $2.1-2.3$ an $\mathrm{x}$ amount of times.

Stage 2.1. Substitute $i=i+1$. Generate solution $E \in N\left(E_{i-1}\right)$.

Stage 2.2. If $F(S+E)<F_{\text {best }}$ then substitute $E_{\text {best }}=E, F_{\text {best }}=F(E)$.

Stage 2.3. If $F(S+E)<F\left(S+E_{i-1}\right)$ then substitute $E_{i}=E$. If not, accept solution $E$ with probability $p=\exp \left(\frac{-\Delta}{T_{i}}\right)$, where $\Delta=F(S+E)-F\left(S+E_{i-1}\right)$. Therefore $E_{i}=E$, if solutions $E$ or $E_{i}=E_{i-1}$ were accepted, unless solution $E$ was not accepted .

Stage 3. Calculate $T_{i}$ according to the specified cooling scheme.

Stage 4. If $T_{i}>T_{N}$ go to step 2, otherwise STOP.

Stage 5. The produced solution requires approval by the decision-maker concerning its implementation. Approval can be complete (all new links are approved) or partial (approval of only a part of new links). In the case of partial approval, the set of acceptable solutions should be narrowed, the set of prohibitions should be expanded to include unacceptable links that were accepted and repeat the calculation procedure (return to stage $\mathbf{0}$ ) in order to generate new links to approve by the decision-maker.

The algorithm features Boltzmann's approval function, a geometric cooling scheme, i.e. $T_{i}=\lambda T_{i-1}$ and $\mathrm{T}_{0}=0.01, \lambda=0.99, \mathrm{~T}_{\min }=0.0001$. The number of considered solutions at a set temperature depends on the number of links being introduced and based on experiments a value of $x=5 \cdot c_{e}$ was used (stage 2).

The algorithm was applied using the Python programming language, using the networkx package to analyse social networks.

\section{Case Study}

\subsection{PROJECT DESCRIPTION}

The analysed project is associated with the construction of a housing complex (four multi-family residential buildings with a total usable area of $12000 \mathrm{~m}^{2}$ ), located in Katowice. Construction began at the start of 2016, while completion has been planned for September 2019. The project budget is 40 million PLN. Initially, the project was carried out in a system featuring a general contractor, however, as of October 2018, due to a worsening situation on the construction market, the General Contractor filed for bankruptcy. The completion of the project required the developer to hire management staff and sign contracts directly with contractor companies specialising in each branch of construction. As a result, a new formal project organisation structure was created. Proceeding with construction work also gave rise to a new, informal (self-organising) structure of relationships between new participants in the carrying out of the project, which, as it later turned out (demonstrated in the study by [19].), was different from the contractual information sharing structure. 


\subsection{SELF-ORGANISING INFORMATION SHARING MODEL AND DYSFUNCTION}

\section{DETECTION}

Based on data gathered at the construction site, a network model of information sharing between project actors was developed, whose nodes represent individuals or companies (contractors, design companies, etc.) while links represent communications connections between them and in the context of information sharing concerning technical matters associated with carrying out finishing works [19]. Network model structural analysis demonstrated numerous dysfunctions among project participants, a description of which can be found in the article by [19]. One of the more significant dysfunctions was the role of the developer supervision coordinator, who was practically the only person controlling the flow of information (a disproportionately high betweenness centrality value relative to other actors), which required a detailed investigation of the cause of the situation. However, the fundamental dysfunction concerning the process of information sharing was the low significance of the role of the Site manager (low centrality measure values presented in chapter 3.1), which, from the point of view of the formal, contractual organisational structure, as well as on the basis of construction law, should have been much more prominent.

\subsection{OPTIMISATION TASK FORMULATION AND ITS ANALYSIS}

The dysfunction concerning the Site manager required intervention in order to improve their position in the self-organising information sharing network. Due to the fact that the identified measure of betweenness centrality for the Site manager caused a significant lowering of their position in the network (figure 5b), it was imperative to increase this measure first (goal function weight for this measure was set at 0.8 ). For the remaining two centrality measures (figures $5 \mathrm{a}$ and $5 \mathrm{c}$ ), the priority of increasing them was lower (a weight of 0.1 set for both). Because of this, additional links had to be introduced between appropriate network nodes in order to increase the structural measures of the Site manager's centrality. The number of required new links was to be as low as possible because of the costs of forming new connections and the operational costs associated with maintaining them [1]. An additional constraint concerning an optimal intervention is identifying undesirable connections between construction project participants, who should not or do not have to exchange information due to formal and factual reasons. In order to analyse the optimisation task formulated in this manner, the authors used the proposed SA-based algorithm. A review of optimal solutions depending on the number of links introduced into the network was performed (from 1 to 30 ). For instance, figure 6 shows the course of the calculations for the simulated annealing algorithm for introducing 23 links. 

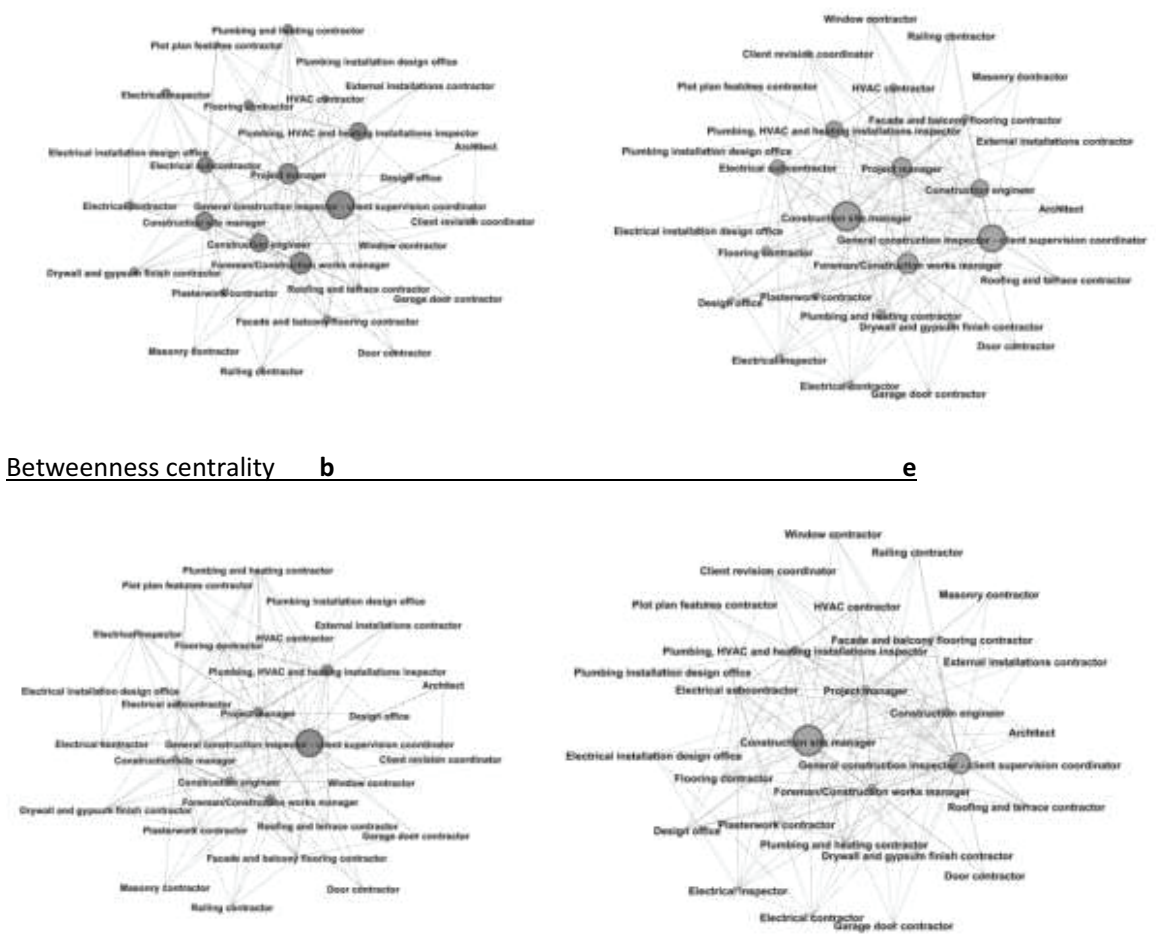

Eigenvector centrality
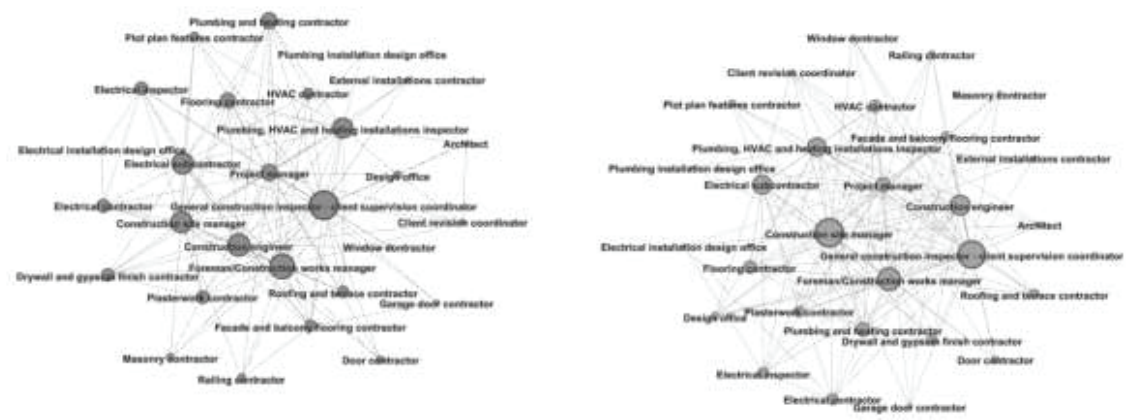

Fig 5. Self-organising non-weighted network of information flow between construction project participants and their structural measures of centrality prior to optimisation (network a, b, c) and after optimisation $(\mathrm{d}, \mathrm{e}, \mathrm{f})$. The values of participant centrality measures is defined by the diameter 
of their corresponding node (the larger the node the higher the value of the given measure). The computer program "Gephi" was used to visualize and analyze the network structure

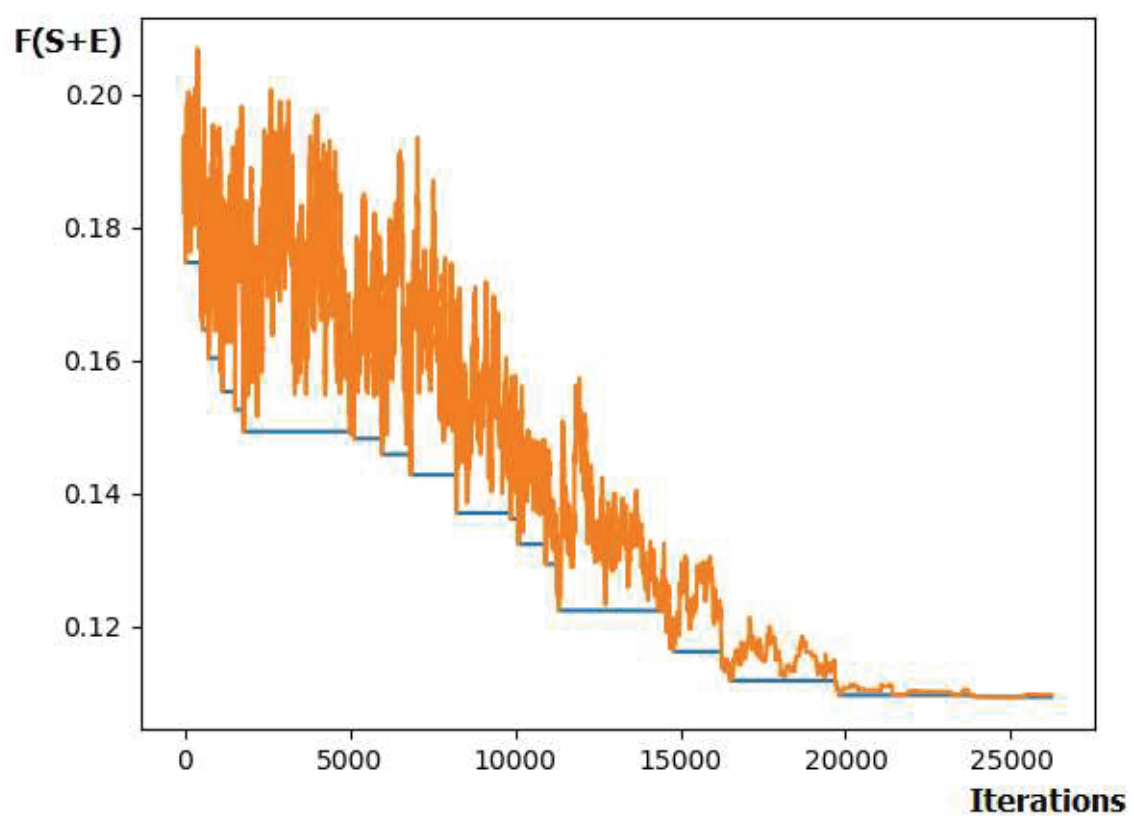

Fig 6 Plot of the simulated annealing algorithm for the introduction of 23 links.

The solution that was obtained (which was to be at least suboptimal), maximally increases the value of structural measures of centrality for the Site manager, which caused their position to become the most significant in the self-organising network. This corresponded with the number of 23 new links (accepted and approved by the decision-maker) which had to be introduced into the network structure. Further increasing the amount of new links caused the result to be less optimal (fig. 7). It should be noted that the values of individual centrality measures for the Site manager become greater than those of the Developer supervision coordinator for a much lower number of new necessary connections, which, considering the postulate of minimising communication costs (the cost of building a link and the operational cost of maintaining it) should be taken into consideration. 


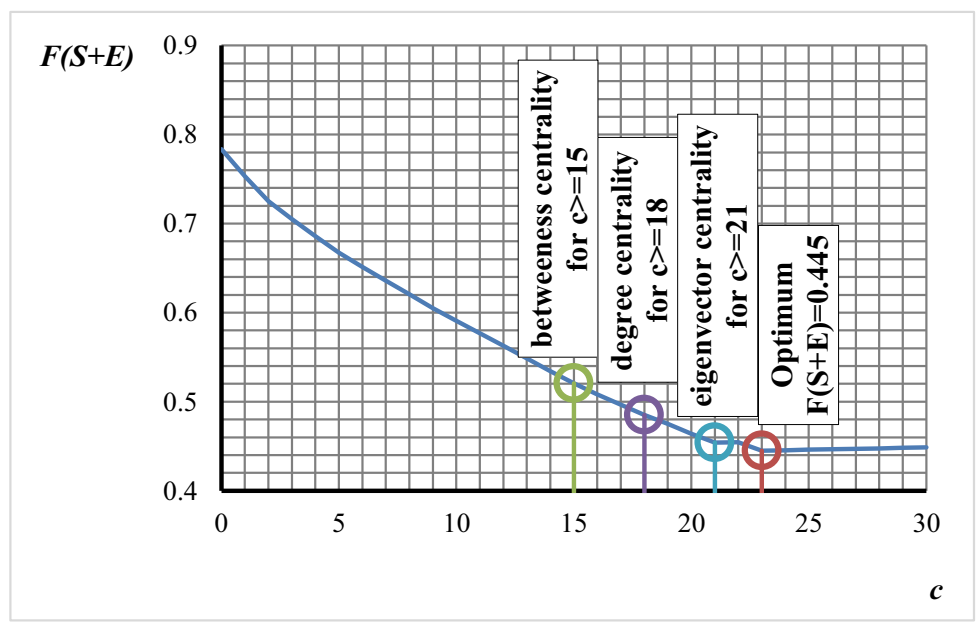

Fig 7. Minimum goal function values relative to the number of new connections to be introduced within the self-organising information sharing network. Also: the number of new connections for which values of individual centrality measures of the Site manager outrank the measure values of the Developer supervision coordinator, which had previously been the highest.

In conclusion, it should be noted that there is no need to stop at removing the dysfunctions concerning the Site manager in the presented example. The proposed optimisation model and its analysis method makes it possible to simultaneously plan an intervention meant to remove dysfunctions of a larger number of project participants with identified dysfunctions, which makes analysis more complicated and can lead to more complex results..

\section{CONCLUSION}

Over the course of carrying out a construction project, its participants exchange among themselves various pieces of information necessary to fulfil basic goals (e.g. concerning necessary changes to the design, work schedule changes, etc.). Typically, the formal, contractual organisation structure of such a project (if set for a given project) regulates who should contact whom. However, it turns out that construction project participants search for connections that make it easier for them to fulfil their roles within the project ("quickly, efficiently and to maximise profit under conditions of uncertainty"), which does not always reflect formal decisions [2]. The topography of such selforganising networks of information sharing between participants is complex and dynamic. These hidden relationships can be mapped in the form of social networks, while the SNA method (Social network analysis) can be used to perform their structural analysis. Analysing such networks makes it possible to identify various informal roles that actors play depending on their positions within the network structure. Literature studies have shown that the more central the position of a given 
participant in the context of information flow wihin the communication network, the greater their coordination activity. Change in the structural position of participants leading to the elimination of any dysfunctions in the network structure requires the intervention of management staff [15]. Management staff (decision-maker) interventions should be optimal and effective in terms of achieving their set goals [20,2]. The optimisation model developed for this purpose, along with its analysis algorithm, can support decision-makers in eliminating dysfunctions of some construction project participants. The approach presented by the authors does, however, have some limitations, that the authors will take into consideration in further work. First, the optimisation model and its analysis method refers to non-weighted networks and therefore only involves communication links and their orientation between network actors while ignoring significant elements like the frequency and quality of information flow [19]. Second, the case study presented by the authors only applied to communication between construction participants on technical matters. There is also a need for other communication contexts (e.g. matters of payment, schedules or health and safety) to be considered in parallel, which in practice requires simultaneously analysing several information flow networks as a part of a single project. The aspects outlined above will be taken into consideration in future articles by the team of authors.

\section{REFERENCES}

[1] Pryke, Stephen. Managing networks in project-based organisations. John Wiley \& Sons, 2017.

[2] Pryke, Stephen, et al. "Self-organizing networks in complex infrastructure projects." Project management journal 49.2 (2018): 18-41.

[3] Winter, Mark, et al. "Directions for future research in project management: The main findings of a UK government-funded research network." International journal of project management 24.8 (2006): 638-649.

[4] Hanisch, Bastian, and Andreas Wald. "A project management research framework integrating multiple theoretical perspectives and influencing factors." Project Management Journal 42.3 (2011): 4-22.

[5] Moreno, Jacob Levy. "Who shall survive?: A new approach to the problem of human interrelations." (1934).

[6] Loosemore, Martin. "Construction crises as periods of social adjustment." Journal of management in engineering 13.4 (1997): 30-37.

[7] Loosemore, Martin. "Social network analysis: using a quantitative tool within an interpretative context to explore the management of construction crises." Engineering, construction and architectural management 5.4 (1998): 315-326.

[8] Brookes, N. J., et al. "Social processes, patterns and practices and project knowledge management: A theoretical framework and an empirical investigation." International Journal of Project Management 24.6 (2006): 474-482.

[9] Larsen, Graeme D. "Understanding the early stages of the innovation diffusion process: awareness, influence and communication networks." Construction Management and Economics 29.10 (2011): 987-1002.

[10] Pryke Stephen . Social network Analysis in Construction, Wiley-Black Well, 2012.

[11] Alsamadani, Rayyan, Matthew Hallowell, and Amy Nicole Javernick-Will. "Measuring and modelling safety communication in small work crews in the US using social network analysis." Construction Management and Economics 31.6 (2013): 568-579.

[12] El-Sheikh, Ahmed, and Stephen D. Pryke. "Network gaps and project success." Construction management and economics 28.12 (2010): 1205-1217.

[13] Chowdhury, Abu Naser, Po-Han Chen, and Robert LK Tiong. "Analysing the structure of public-private partnership projects using network theory." Construction Management and Economics 29.3 (2011): 247-260.

[14] Di Marco, Melissa K., John E. Taylor, and Pauli Alin. "Emergence and role of cultural boundary spanners in global engineering project networks." Journal of management in engineering 26.3 (2010): 123-132.

[15] Hossain, Liaquat, and Andre Wu. "Communications network centrality correlates to organisational coordination." International journal of project management 27.8 (2009): 795-811. 
[16] Kratzer, Jan, Roger Th AJ Leenders, and Jo ML Van Engelen. "The social network among engineering design teams and their creativity: A case study among teams in two product development programs." International Journal of Project Management 28.5 (2010): 428-436

[17] Balkundi, Prasad, and David A. Harrison. "Ties, leaders, and time in teams: Strong inference about network structure's effects on team viability and performance." Academy of Management Journal 49.1 (2006): 49-68.

[18] Malisiovas, Andreas, and Xinyi Song. "Social Network Analysis (SNA) for Construction Projects' Team Communication Structure Optimization." Construction Research Congress 2014: Construction in a Global Network. 2014.

[19] Śladowski Grzegorz, Radziszewska- Zielina, Kania Ewelina. "Analysis of self-organising networks of communication between the particimants of a housing complex construction project. " Archives of Civil Engineering 1 (2019)

[20] Donaldson, L. "The contingency theory of organisations." Thousand Oaks, CA: Sage Publications, (2001).

[21] Wasserman, Stanley, and Katherine Faust. Social network analysis: Methods and applications. Vol. 8. Cambridge university press, 1994.

[22] Newman, Mark. "Networks: an introduction." (2010).

[23] Brandes, Ulrik. "On variants of shortest-path betweenness centrality and their generic computation." Social Networks 30.2 (2008): 136-145.

[24] Kirkpatrick, S., Gelatt, C.D., \& Vecchi, M.P. (1983) Optimization by simulated annealing. Science 220, 671680 .

\section{LIST OF FIGURES AND TABLES:}

Fig. 1. Interpretation of degree centrality within a network of information flow [1]

Rysunek. 1. Interpretacja stopnia centralności w sieci przepływu informacji [1]

Fig. 2. Interpretation of eigenvector centrality within a network of information flow [1]

Rysunek. 2. Interpretacja wektora własnego w sieci przepływu informacji [1]

Fig. 3. Interpretation of betweenness centrality in a network of information flow[1]

Rysunek. 3. Interpretacja pośrednictwa w sieci przepływu informacji [1]

Fig. 4. Conceptual scheme of plotting a new solution in environment $N\left(E_{i-1}\right)$

Rysunek. 4. Schemat ideowy wyznaczania nowego rozwiązania w otoczeniu $N\left(E_{i-1}\right)$

Fig.5. Self-organising non-weighted network of information flow between construction project participants and their structural measures of centrality prior to optimisation (network a, b, c) and after optimisation $(\mathrm{d}, \mathrm{e}, \mathrm{f})$. The values of participant centrality measures is defined by the diameter of their corresponding node (the larger the node the higher the value of the given measure).

Rysunek. 5. Samoorganizująca się nieważona sieć przepływu informacji pomiędzy uczestnikami realizacji budowy i ich strukturalne miary centralności przed optymalizacją (sieć a,b,c) i po optymalizacji (sieć d,e,f). Wielkości miar centralności uczestników określa średnica odpowiadającego im węzła (im większa średnica tym wyższa wartość danej miary)

Fig. 6. Plot of the simulated annealing algorithm for the introduction of 23 links.

Rysunek. 6. Przebieg algorytmu symulowanego wyżarzania dla wprowadzonych 23 łuków.

Fig.7. Minimum goal function values relative to the number of new connections to be introduced within the self-organising information sharing network. Also: the number of new connections for which values of individual centrality measures of the Site manager outrank the measure values of the Developer supervision coordinator, which had previously been the highest.

Rysunek. 7. Minimalne wartości funkcji celu względem liczby nowych połączeń do wprowadzenia w analizowanej samoorganizującej się sieci wymiany informacji. Dodatkowo liczba nowych połączeń, dla których wartości poszczególnych miar centralności kierownika budowy przekraczają, pierwotnie największe w sieci, wartości miar koordynatora nadzoru inwestorskiego. 


\section{ZARZADZANIE PRZEPLYWEM INFORMACJI W SAMOORGANIZUJĄCEJ SIE POMIEDZY UCZESTNIKAMI REALIZACJI BUDOWY}

Keywords: Analiza sieci społecznych (SNA), zarzadzanie w budownictwie, optymalizacja, przepływ informacji

\section{STRESZCZENIE:}

W toku realizacji przedsięwzięcia budowlanego jego uczestnicy wymieniają między sobą różne informacje potrzebne aby zrealizować postawione cele (np. w zakresie koniecznych zmian w projekcie, zmian w harmonogramie prac itd.). Zwykle formalna, umowna struktura organizacyjna takiego przedsięwzięcia (jeżeli w ogóle jest opracowana) reguluje kto z kim powinien się kontaktować. Okazuje się jednak, że uczestnicy realizacji budowy szukają takich połączeń, które ułatwiają wypełnianie ich ról w przedsięwzięciu (,szybko i sprawnie, aby zmaksymalizować zysk w warunkach niepewności”) co nie zawsze odpowiada formalnym ustaleniom [2]. Jak wynika z badań wiele kluczowych decyzji w przedsięwzięciach budowlanych podejmowana jest właśnie $\mathrm{z}$ perspektywy tych nieformalnych (niewidocznych $\mathrm{z}$ perspektywy formalnych struktur organizacyjnych) relacji pomiędzy uczestnikami [2]. Topografia takich samoorganizujących się sieci wymiany informacji pomiędzy uczestnikami jest złożona i dynamiczna. Te ukryte relacje mapowane mogą być w formie sieci społecznych a do ich analizy strukturalnej można użyć metody SNA (Social network analysis). Analiza takich sieci pozwala na identyfikację różnych nieformalnych ról, które uczestnicy odgrywają w zależności od ich pozycji w strukturze sieci. Literatura przedmiotu ukazuje związek między pozycją strukturalną uczestników sieci komunikacyjnej a ich działaniami koordynacyjnymi, rozumianymi jako zorganizowany proces zarządzania zasobami w projektach budowlanych. Im bardziej centralna jest pozycja danego uczestnika w kontekście przepływu informacji w sieci komunikacyjnej, tym większa jest jego koordynacyjna aktywność. Zmiana pozycji strukturalnej uczestników prowadząca do wyeliminowania wszelkich dysfunkcji w strukturze sieci wymaga interwencji kadry zarządzającej [15]. Ingerencja kadry zarządzającej (decydenta) powinna być optymalna i efektywna w kontekście osiągnięcia założonych celów [20,2]. Celem artykułu jest zaproponowanie optymalizacyjnego podejścia do planowania takich interwencji z uwzględnieniem różnych ograniczeń, w tym kosztów takiej komunikacji. W ramach optymalizacji autorzy zaproponowali metodę z grupy metod heurystycznych. Metodę zaprezentowano na przykładzie rzeczywistego przedsięwzięcia budowlanego związanego z realizacją osiedla budynków wielorodzinnych. Struktura samoorganizującej się sieci została określona w oparciu o badania ankietowe wśród uczestników początkowej fazy realizacyjnej przedsięwzięcia, dotyczące komunikacji między nimi w okresie ostatnich 4 tygodni. W wyniku analizy strukturalnej sieci stwierdzono nieprawidłowości w komunikacji pomiędzy uczestnikami tego przedsięwzięcia $\mathrm{w}$ szczególności w komunikacji z kierownikiem budowy. Wykryta dysfunkcja kierownika budowy wymagała interwencji w celu poprawy jego pozycji w samoorganizującej się sieci wymiany informacji. Ze względu na fakt, że zidentyfikowana miara strukturalna pośrednictwa w sieci (betweeness centrality) w przypadku kierownika budowy wykazała znaczne obniżenie jego pozycji w sieci (duża część informacji nie docierała do kierownika budowy, co obniżyło jego kontrole nad jej przepływem) (rysunek 5b), miarę tą należało więc podnieść w pierwszej kolejności (waga w funkcji celu dla tej miary wynosi 0.8 ). Dla pozostałych dwóch miar centralności (rysunek 5a,5c) priorytet ich zwiększania był mniejszy (waga po 0.1 ). W zawiązku z tym należało wprowadzić dodatkowe połączenia pomiędzy odpowiednimi węzłami w sieci w celu zwiększenia strukturalnych miar centralności kierownika budowy. Liczba koniecznych nowych połączeń powinna być jak najmniejsza ze względu na koszty budowy nowego połączenia oraz koszty operacyjne związane z jego utrzymaniem [2]. Dodatkowym ograniczeniem w ramach optymalnej interwencji było wskazanie niepożądanych połączeń pomiędzy uczestnikami realizacji budowy, którzy z powodów formalnych i merytorycznych nie muszą albo nie powinni się wymieniać informacjami. Do analizy tak sformułowanego zadania optymalizacyjnego użyto zaproponowanego algorytmu opartego na SA. Dokonano przeglądu optymalnych rozwiązań w zależności od liczby wprowadzonych łuków do sieci (od 1 do 30). Otrzymane rozwiązanie (co najmniej suboptymalne) maksymalnie zwiększyło wartość strukturalnych miar centralności kierownika budowy co spowodowało, że jego pozycja w samoorganizującej się sieci stała się najbardziej znacząca. Odpowiada temu liczba 23 nowych (zaakceptowanych a więc dopuszczonych przez decydenta) połączeń, które należy w tym celu wprowadzić do struktury sieci. Dalsze zwiększanie liczby nowych połączeń spowodowało by w tym przypadku pogorszenie wyniku (rysunek 7). Dodatkowo zwrócono uwagę, że wartości poszczególnych miar centralności kierownika budowy przekraczają, pierwotnie największe w sieci, wartości miar koordynatora nadzoru inwestorskiego dla znacznie mniejszej liczby nowych połączeń koniecznych do wprowadzenia, co przy postulacie minimalizowania kosztów komunikacyjnych (koszt budowy połączenia i kosztów operacyjnych jego utrzymania) powinno być wzięte pod uwagę. Uzyskane 
rozwiązanie wspomoże podejmowanie decyzji w zakresie ingerencji w sieciową strukturę nieformalnych relacji. Należy na koniec zwrócić uwagę, że w zaprezentowanym przykładzie nie ma konieczności ograniczania się tylko do likwidacji dysfunkcji kierownika budowy. Zaproponowany model optymalizacyjny i metoda jego analizy pozwala planować równocześnie interwencję w stosunku do większej liczby uczestników tego przedsięwzięcia, u których wykryto dysfunkcje, co czyni analizę bardziej skomplikowaną i może prowadzić do bardziej złożonych wyników. Opracowana metoda optymalizacyjna wskazała możliwości poprawy komunikacji w takiej sieci. Efekty analizy potwierdziły potencjał aplikacyjny przedstawionej metody.

Received 15.04.2019

Revised 30.04.2019 